\title{
Developing Education in Vietnam in the Context of International Integration
}

\author{
Nguyen Minh Tri \\ Politics and National Defense Education Center, Ho Chi Minh City University of Technology (HUTECH),475A Dien \\ Bien Phu Street, Ward 25, Binh Thanh District, Ho Chi Minh City, Vietnam. \\ *Corresponding author. Email: nm.tri@hutech.edu.vn
}

\begin{abstract}
With a lofty goal and mission, it is the mission of "cultivating people". Education and digging have an important role in the development of society. Education trains people with good knowledge and expertise and trains people with good moral and physical qualities, effectively serving the socio-economic development associations of each country, each ethnic group.

Today, all countries globally, including Vietnam, consider investing in education and training to be an investment in development for today's generation and the next generation and identify education and training development as a top national policy. In the context of international integration, Vietnam's education faces many difficulties and challenges when our education is still too heavy on transmitting knowledge but not directed to the quality and capacity development of learners; the quality of the contingent of teachers and administrators is not equal; The infrastructure system still has many limitations. The problem is that Vietnam needs appropriate solutions to develop education to meet citizens' requirements in the process of international integration.
\end{abstract}

Keywords: Education, training, international integration, Vietnam.

\section{INTRODUCTION}

In today's era, education and training is the most effective way for people to access the latest information promptly, update, enrich their knowledge and creative capacity; only through education and training can all the resources be trained, developed and promoted effectively. Therefore, from past to present, every country and ethnic group in the development process has highly appreciated the important role of education. Today, people consider education and training to be a special social activity, part of the superstructure and as a factor holding the fundamental position and the driving force in determining the development of socioeconomy; investment in education and training is an investment for the future.

Ho Chi Minh pointed out a particularly important role education plays in the formation and development of people, saying: "An ignorant people is a weak people" [1]; and he pointed out the education's mission and goal: "Learning to work, to be human, to be an officer. Learn to serve the unions, the class and the people, the Fatherland and humanity" [1].
Imbued with that thought, during the revolution as well as in the comprehensive renovation of the country, the Party and State of Vietnam have always paid attention to the development of education, training and affirmed: "Education and Training is the top national policy, the decisive factor for the successful implementation of the cause of national construction and defense; is the cause of the entire Party and people" [2]. Vietnam also affirmed: "Education is the top national policy. To develop education and training to improve people's intellectual standards, train human resources, and foster talents. Strongly shifting the educational process, mainly from equipping knowledge to comprehensively developing students' competencies and qualities; Learning goes hand in hand, reasoning associated with the practice. Education development associates with the needs of socio-economic development, national construction and defense, scientific and technological progress, and requirements for human resource development and the labor market" [3]. This article analyzes the achievements, challenges, and solutions of Vietnam's education development in the current international integration context. 


\section{LITERATURE REVIEW}

Awareness and problem solving education in international integration are a large topic, attracting the research interest of many scientists and many sociopolitical organizations in countries around the world.

Firstly, Jean-Jacques Rousseau mentioned the role of education in the formation and development of human personality in particular and the advancement of society in general, educational objectives, and methods. He also analyzes and deeply evaluates educational principles, the interaction between teachers and learners, as well as builds a future education that he calls "natural education" and later. His name is closely linked to this natural educational philosophy [4]. Along with this topic John Dewey presented on the philosophy of active education - the true value of knowledge in applying that knowledge, the vitality of knowledge is that knowledge is associated with action; on the role and function of education; the thought of building a progressive education - is an active education with specific educational goals, flexible, creative, suitable for nature and achieving social efficiency; and an education in a democratic society - an education that cares about the problems of ordinary people in society [5].

In Vietnam, Thomas J. Vallely discussed the history of Vietnam's educational development over the past decades, especially emphasizing efforts to overcome various challenges to achieve current achievements, in which, he spends more than eight pages discussing policies for developing teaching staff and educational management, mobilizing all resources in society to develop education. Finally, the report draws on three lessons learned: firstly, the Vietnamese government has always considered education and training, science and technology to be the top national policy; Secondly, the Vietnamese education system must be developed fundamentally and comprehensively in the direction of democratization, socialization, diversification, standardization and modernization; Thirdly, the innovation in educational management in Vietnam starts from new thinking about educational development [6].

Marxist views on the cause of education; educational science and educational development experience; educational development direction; the role of education in economic, social, political development and a number of issues posed to our education sector when entering the twenty-first century... [7]. The following studies, presenting the current educational situation of our country, the context, opportunities and challenges for our country's education in the next few decades, the views guiding the development of education; education action programs have concretized the goals, guidelines, policies and solutions for educational development in Vietnam [8].
In addition, there are also articles and speeches of leaders, former leaders of Party and State agencies, central and local agencies, managers and scientists to contribute to the success of the fundamental and comprehensive renovation of education and training in Vietnam [9].

\section{METHODS}

\subsection{Purpose}

In international integration, the development of education in Vietnam, Vietnam has positively contributed to socio-economic development. However, education in Vietnam still has many shortcomings, not really meeting the requirements of industrialization and modernization. The problem is that Vietnam needs appropriate solutions to develop education to meet citizens' requirements in the international integration process.

\subsection{Methodology}

The article uses various research methods, such as historical and logical methods, collation and comparison, analysis and synthesis, inductive and interpretation, and statistical methods from reference sources to serve in research and article presentation.

\subsection{Main Findings}

Education development in Vietnam over the past time has contributed positively to the people's education, fostering talents, training human resources for socioeconomic development. However, the development of education in Vietnam today has not "become the top national policy". In order to further develop education in the international integration process, it is required that the Government have appropriate solutions and policies in the coming time.

\subsection{Applications}

The research findings can be used to provide key planning recommendations for the development of education in the international integration process.

\section{RESULTS AND DISCUSSION}

\subsection{The main achievements of Vietnamese education}

Firstly, with regards to the Early Childhood Education.

According to a report by the Ministry of Education and Training, in the 2013-2014 school year, only 18 provinces and cities were recognized as meeting the standard of universal preschool education for children 5 years old, by 2017 , this figure was $63 / 63$ provinces and cities; The network of schools and preschool classes is growing day by day, the rate of non-public schools and classes has increased rapidly. The rate of mobilization of children exceeds the target at all ages. In August 2018, 
the Government unanimously agreed on the policy of implementing the policy of free tuition for preschool children five years old and supporting the payment of tuition fees for non-public base school for universal children, especially for children in rough villages and communes, areas with ethnic minorities, remote and isolated areas [10]. This policy is deeply reflected in the efforts and determination to raise the intellectual level of the people for all strata of the people and all regions of the country to have access to education, as well as to provide social protection for the disadvantaged to create a development of gratitude, humanity, justice and social progress in the process of industrialization, modernization and international integration in Vietnam today.

\section{Secondly, with regard to the general education.}

High schools' facilities are getting more and more attention, since then the scale of education is also expanding. If the 2010-2011 school year, the number of schools is 28,593 , by the $2018-2019$ school year, it will increase to 28,710 ; the number of teachers increased by nearly 1.2 times (reaching 853 thousand teachers), and the number of students was 18.7 million, of which the number of high school students was over 2.5 million with the graduation rate $97,94 \%$ (the school year 2018 2019); the number of vocational secondary and professional high school students in 2018 and 2019 is about 600 thousand people. Thus, in total, over $67 \%$ of young people in the age group have attained high school education and the equivalent [11].

The universalization of primary and lower secondary education has been strongly deployed in localities, creating opportunities and basic conditions for a part of the population to study at higher educational levels according to needs and the ability to, and attention to, particularly difficult areas (upland, remote, and mountainous areas), subject to ethnic minorities, the poor, and social policy beneficiaries. The country has achieved national standards on illiteracy eradication and primary education universalization (in 2000); by the end of 2010, most of the provinces and cities will reach the lower secondary education standards; the national literacy rate of the population aged 15 and over is $95.1 \%$; $100 \%$ of provinces and cities meet the standards of preschool universalization [11]. Basically, our country has achieved equality between men and women in primary education. Social equity in education has been improved, especially for girls, ethnic minorities and children from poor families, and the most disadvantaged groups in society. Education in ethnic minority, remote, and isolated areas has seen positive changes, continuing to develop thanks to the effective promulgation and effective implementation of education policies for ethnic minorities strongly.

With the relentless efforts of students and teachers across the country, the education sector has also achieved a lot of success from scientific research, winning many medals from international and regional Olympic competitions. The Vietnamese students' delegations participating in the Asian and international Olympic competitions in cultural subjects achieved high results, with 38/38 high school students participating in the regional and international Olympic competitions. This is the best ever achievement, including the student with the world's highest scores. Some teams have stable achievements, ranking high in exams such as Math, Physics, and Computer Science. According to the Ministry of Education and Training, in recent years, the achievement of students competing in international and regional competitions next year has been improved compared to the previous year and has left a deep impression on the hearts of international friends in general education as well as about the country and people of Vietnam.

Thirdly, with regard to the scale of education.

The scale of education has increased rapidly, especially at university level and vocational training, initially meeting society's needs. The number of vocational training schools has grown rapidly. According to the General Statistics Office in 2019, Vietnam has 235 universities and institutes (including 170 public schools, 60 private and private schools, 5 schools with $100 \%$ foreign capital), 37 scientific research institutes are assigned the task of training doctoral level, 33 pedagogical colleges and 2 pedagogical intermediate schools. In addition, intermediate training also has an increase from 238 schools in 1996 to 303 schools in the 2017-2018 school year. Along with the increase in the number of schools and classes is an increase in human resources training, the year after is always higher than the previous year. The number of students and graduates increases by $10-12 \%$ on average each year.

Fourthly, with regard to the work of socialization in human resource training.

The rapid development of technical education institutions, tertiary training institutions, and colleges with increasing education and training budgets as well as the implementation of supportive policies for poor localities, poor households, and other disadvantaged people have created conditions for urban and rural workers, the rich and the poor to access training and vocational training programs. In addition, investment resources for education are diversified with flexible mobilization, suitable to each locality's economic capacity and conditions, each stage and individual, increasingly bringing about the positive effect in training human resources of the country. Simultaneously, the types of schools and classes have been diversified. There have been more private schools and classes. Distance education programs through the mass media have been gradually strengthened. For public schools, the State has issued and gradually improved the regime of collecting 
tuition fees and other contributions, creating more financial resources for these schools. The non-public schools system continued to expand, creating conditions for reducing pressure on public schools and creating opportunities for social forces and the State to participate in education.

Thus, after more than 30 years of renovation, Vietnam's education has obtained many important achievements, a relatively complete, unified and diversified national education system has been formed with a full range of education levels and training levels from preschool to postgraduate; especially, creating learning opportunities and conditions for ethnic minorities, remote and isolated areas, and children from poor families have made remarkable progress. The education system has been initially diversified in terms of both types, modes, and resources, gradually integrating with world education's general trend. From an education system with only public schools and mainly formal ones, up to now there are non-public schools, there are many types of informal schools, there are open schools, with training methods from long-distance, training association mode with foreign countries. Evaluating the achievements in Vietnam's educational development, our Party affirmed: "The scale and network of educational and training institutions continue to be expanded. The education and training system at all levels from foundation to university and vocational training has been reorganized one step. The quality of education and training has improved. Facilities, educational, and training equipment have been improved and modernized. The teaching staff and educational administrators have developed both in quantity and quality. Educational socialization has been accelerated " [3].

\subsection{Difficulties and challenges in Vietnamese education}

Firstly, the quality of education and training has not yet met the development requirements, especially the training of highly qualified human resources is still limited. Although the education sector has seen many development steps in the reforming years, we are still too focused on increasing the quantity and scale of training but not paying attention to the quality. Curriculum, content, and teaching methods are the most decisive factor in improving the intellectual level of the people as well as the quality of human resources. However, the curriculum, content, and teaching methods are still backward. We pay too much attention to teaching knowledge but do not pay much attention to teaching skills, manners, culture, ethics for employees. Teaching knowledge is mainly inclined to theory; teaching very little practice, usually only in the last few months of the course. Although we have also made many efforts to innovate teaching methods, encourage active, studentcentered teaching methods, for many reasons, traditional methods still prevail, new methods have not made any change. All those limitations of the education and training industry are clearly shown on its products: the low quality of human resources. Employees still lack industrial style, labor discipline, and professional ethics, some of them are slow to adapt to the market mechanism, the organization and discipline are not good, the level of scientific and technical application and poor technology... In general, Vietnamese workers lack many qualities, capacities, and skills compared to socio-economic development requirements in the current fierce global competition. Compared with other countries in the region, our country's ranking for the quality of human resources is very low. If calculated on a scale of 10 , the quality of human resources in Vietnam only reached 3.79 points, while South Korea is 6.91 points; India is 5.76 points; China is 5.73 points; Malaysia is 5.59 points.

Secondly, the school's material facilities and technical foundations are inadequate and outdated. Equipment and laboratories for teaching and learning are in short supply, and teaching is still common in traditional ways. The number of computers is small; many students do not have enough textbooks in difficult areas. In recent years, the scale of education has grown, the number of colleges and universities has increased sharply, while the conditions of faculty and school facilities have not yet developed but still exist, the schools enroll students again, and then issue diplomas, so unemployment is inevitable. According to statistics from the Ministry of Labor, Invalids and Social Affairs in 2018, more than 100,000 bachelor's are unemployed, still 70,800 people with college degrees are still unemployed, while $41 \%$ of enterprises cannot recruit enough workers. High-skilled labor; In the first 3 months of 2018, the number of new job searches increased by about $40 \%$ over the same period in 2017 . This is really a paradox, a "bottleneck" for Vietnam's education development today.

Thirdly, although equity in education and training has been improved, there are still shortcomings. This is reflected in ensuring that minimum education (lower secondary education) has been achieved at the national level, but the proportion of students who have not attended school is still high, especially in mountainous areas, ethnic minorities. According to data from the Ministry of Education and Training, about $3.6 \%$ of students in the age group cannot go to school every year. The proportion of students in regions with extremely difficult socio-economic conditions and dropout rates is higher than in key economic regions and urban areas (Red River Delta, dropout rate 2.96\%; the Northwest region 6.91\%; Central Highlands is $17.16 \%$ and the Mekong River Delta is $12.64 \%$. In mountainous areas, the number of illiterate girls in the 10-year-old group is $13.69 \%$; the age group $11-14$ is $7.98 \%$; the $15-17$-yearold group is $9.08 \%$. In terms of ethnic groups, the number of illiterate girls in the Mong is $90 \%$, Ha Nhi $89 \%$, Gia Rai $83 \%$, Bana $82 \% \ldots$ )

Fourthly, the teaching staff is both weak, lacking and asynchronous. Teachers play a decisive role in the 
quality of education and training, but in fact, when the size of students rapidly increases, there is a mismatch between the scale of education development with the teachers, especially in Preschool and university level. There is a phenomenon of lack of teachers and redundancy due to lack of uniformity in types. Many localities have enough, or even redundant, teacher staff, but lack the types of teachers such as foreign languages, music, and technology. The shortage of highly qualified teachers in universities is increasing, the average age of teachers is high.

Fifthly, the state management of education and training still has many weaknesses and shortcomings that have not kept pace with the innovation in all fields of the country. Some of the above facts show that the development of education and training in our country has had undeniable successful results over the past time. However, Vietnam currently lacks an overall strategy for building, developing, and using national human resources. The biggest limitation is that economic development strategies and human resource development strategies do not go hand in hand. Economic strategymaking agencies and social strategic-making agencies have not really come together on the same path, nor are they acutely acumen in advising the Party on newly emerging complex issues, lack of synchronous and reasonable macro-level decisions to promote education development; some education policies are still subjective, willful, far from reality, and lack social consensus. Educational thinking is slowly being reformed, failing to keep up with national renewal and development requirements in the context of international integration. Therefore, it leads to redundancy that is lacking in many training areas.

Sixthly, the educational system that is heavy on exams and the moral decline in overcoming education is slowly becoming a social pressing. The exam-heavy education system also puts pressure on candidates and parents, leading to a permanent coping mentality in learners and achievement races of teachers, schools, and parents. The disease of achievement and fraud in exams has been rampant in education and society. Education in Vietnam has a long tradition based on the motto "study manners first and then learn to read and write". That is a precious legacy. Each era explains this motto in its own way, but the most common one is still upholding moral values, promoting being human. But unfortunately, those values are being eroded, with the phenomenon taking place in the education and teaching public opinion wave over time.

On the opposite side, there are cases where students or parents violated teachers: Male students in Ben Tre insulted and strangled the teacher in front of the class; male student Quang Binh pierced the teacher's stomach. In early December, a woman in Bac Lieu school cursed and filmed a Facebook clip insulting the teacher because her daughter's pants were lost and most recently, students beat the teacher and had to be hospitalized.

The above phenomena are a wake-up call to Vietnamese education before the current decline in education ethics. They need to be promptly rectified in order to build the Vietnamese people both "red" and "expert" effectively serving the construction of socialism today.

Our Party has clearly pointed out the above difficulties and challenges: "Education and training have not really become the top national policy, a driving force for development. The quality and effectiveness of education and training are still low compared to requirements, especially higher education, vocational education...; still heavy in theory, lightly practiced. Training lacks link with scientific research, production and business and the needs of the labor market; not paying due attention to the education of morality, lifestyle and working skills" [3].

The main reason is due to:

(i) The point of view on education that is the leading national policy has not been fully understood at all education management levels and direction. Many ministries, branches, and localities are not fully aware of the role and mission of education, have not fully seen their responsibilities for education, so they have not given adequate priority to facilitate educational development;

(ii) Innovative thinking, developing education and training in our country in recent years, has not really met the requirements of Vietnam's socio-economic development in the process of international integration leading to internal content, outdated educational methods; The quality and efficiency of education and training are still low, the quality of human resources is inadequate, the rate of workers with high professional qualifications and skills remains low. The training profession is not really linked to the labor market demand. A part of young workers who have been formally trained yet have no job or do things contrary to the training profession, profession, or field;

(iii) The teaching staff has not yet met the educational requirements in the new era, leading to the fact that the teaching staff is redundant, insufficient, and unbalanced in terms of qualifications and expertise. In universities and colleges, the number of masters and doctors is too small (accounting for only about 15\%), so it does not meet human resource development requirements. Training methods in pedagogical schools are slow to be reformed. The expertise, profession, and ethics of the teachers' division have not met the requirements of improving human resources quality. Mechanisms and policies towards teachers are not satisfactory, have not created a driving force to strive for growth within each teacher;

(iv) Education socialization is slow because the State has not issued synchronously and fully legal documents 
and operational guidance documents, as well as the coordination between central and local agencies. There is a lack of strict management of non-public educational institutions.

\subsection{Solutions to develop education in Vietnam}

Firstly, strongly renovate teaching and learning content, programs and methods at all educational levels, specifically: For preschool, focusing on developing schools and classes in industrial zones, manufacturing area; step up solutions to improve the effectiveness and efficiency of state management of preschool education, reduce child violence and solve the shortage of teachers. For high school level, it is necessary to ensure that all people of school age can go to school, especially in rural and remote areas; focus on intellectual and physical development, quality formation and citizenship, discovering and fostering talents, and career orientations for students in accordance with each development stage of the country. In terms of educational content, first of all, it is necessary to focus on equipping learners with basic knowledge so that students can prepare for life. In terms of methodology, it is necessary to use a common and thorough advanced educational method to combine modern with tradition, do well in career guidance, and create a close connection between high schools with universities, colleges, intermediate schools and vocational schools in each locality. Improve the quality of exam organization, especially the national high school exam; enhancing ethical education, lifestyle and life skills for students; implementing and renovating management mechanisms in high schools. To rapidly increase the training scale for vocational colleges and vocational secondary schools for industrial parks, driving economic regions and for labor export. Focus on training skills and expertise based on the actual needs of each different locality of the country through forms of selftraining, strengthening the linkage of businesses and demand-based training institutions. Higher education focuses on training qualified workers suitable to the process of economic restructuring, focusing on human resources for industries with high technology content and added value. Ensuring high-quality labor demand for occupations that are Vietnam's strength in accordance with the context of international integration, meeting the needs of the society so that the proportion of graduate students with jobs suitable for their majors is increasing.

Link teaching and learning with practice. Education needs to simulate and prepare learners to enter real life as much as possible when technology has made accessibility to knowledge easy, making knowledge no longer mean "insurance" for the learners' future as before. One of the appropriate approaches is to increase science, technology, engineering and math (STEM education) education in schools. Accordingly, students will be equipped with knowledge associated with their applications in practice; experience in technology exploration and discovery in association with knowledge learned in the educational program; are encouraged to create science and techniques in order to improve the development of new technologies. This is an interdisciplinary approach to equip learners with knowledge and skills to apply to solve problems in life.

To step by step actively and effectively participate in the regional and international high-tech labor market, first of all, eight occupations (including dentistry, nursing, engineering, construction, accounting, architecture, survey, and tourism) freely move within the ASEAN Economic Community. Carry out well forecasting of demand and labor market both in the short and long term. Based on the overall strategy for human resource development, it is necessary to review and perfect the planning and implement the appropriate planning for the network of universities, colleges and vocational training throughout the country.

Secondly, encourage lifelong learning. One of the most important education goals is to discover and nurture talent and encourage the learners' pursuit, passion, and lifelong learning needs. To this end, a major change is to restructure the system of continuing education centers and community learning centers, and change traditional stereotypes to build lifelong learning centers. This is also the basic solution to fundamentally and comprehensively renovate the education "Perfecting the national education system towards an open education system, lifelong learning and building a learning society".

Thirdly, renovate the state management mechanism of education and training to suit the process of industrialization and modernization in Vietnam. Implement stronger decentralization for departments to properly and clearly manage education and training to promote the creativity of organizations in management, administration and implementation of policies and programs, to promote the role of education and training in socio-economic development; at the same time, to define collective responsibility and individual responsibility, especially the personal responsibility regime of the head, promoting the leadership, leadership and role model in the implementation of education and training. Assigning autonomy and accountability to education and training institutions; implementing the supervision of subjects in the school and the society, strengthening the inspection and examination by management agencies at all levels, ensuring democracy, publicity and transparency.

Fourthly, build and develop a contingent of quality teachers. This is the most decisive breakthrough of the quality of education and training in Vietnam today. The curriculum, textbooks, and equipment are adequate. The study time is reasonable, but the teachers are weak in professional capacity. Poor morality cannot be taught well and there will be no good products. The Ministry of Education and Training should actively develop training plans to foster a contingent of teachers and lecturers to 
prepare for the next 5 to 10 years ... Toward to achieve different types of university qualifications, master pedagogical capacity and profession. Every year, it is necessary to review training plans to send soon training, including overseas training of capable and promising young cadres in teaching and research, to overcome the shortage of local teachers, to improve teachers' ethics.

Fifthly, complete the national education system in an open, modern and connected direction. Complete the national education system in the direction of openness and integration, standardization, modernization, diversification and international integration, meeting the demand for human resources for socio-economic development, in particular attaching importance to training high-quality human resources at all levels. Building a diverse educational system in terms of learning methods, ensuring that all people can learn according to their own wishes and learn for a lifetime in a learning society. Developing an open, modern and interconnected education and training system is the premise for the development of science and technology, exploiting the most and effectively applying the knowledge resources of the nation and people, being a foundation for the industrialization and modernization process as well as for the construction of a knowledge economy in our country; at the same time, strengthening activities of supervision, inspection and examination of the implementation of the law on education and training to promptly handle problems arising in real life.

\section{CONCLUSION}

In today's era, when humanity is entering the knowledge economy and science becomes a direct productive force, especially in the process of international integration, education and training have more and more role and extremely important position for the development of each country, each nation. But in the current lagging situation of our country compared to the general level of the region and the world, if we want to bring Vietnam's education to the advanced level in the region, to meet the requirements of the industrialization to modernization, international modernization and integration, we must quickly fundamentally reform, comprehensively educate and train, must have a determination to choose methodical ways, according to a certain roadmap; building an educational system that fosters innovation and creativity, which emphasizes the importance of lifelong learning and the long-term developmental ability of learners. Moreover, an efficient budget allocation, coupled with a strong political commitment to education and training, will make a difference to the future of Vietnam's young generation.

\section{REFERENCES}

[1] Ho. C. M, Entire episode, ep. 6. Hanoi: National politics, 2011, pp.7-208.

[2] Communist Party of Vietnam, The Resolution of the Eighth Conference of the XI Central Executive Committee, Hanoi: National Political,2013, pp.1

[3] Communist Party of Vietnam, Document of the 12th National Delegation. Hanoi: Central Office of the Communist Party, 2016, pp. 114-115, 113, 113-114

[4] Jean. J. R, Émile, or the problem of education. Hanoi: Knowledge Publishing House, 2008.

[5] John. D, Democracy and Education: Introduction to Educational Philosophy, Hanoi: Knowledge Publishing House, 2008.

[6] Thomas J.V, Education in Vietnam, development, challenges and solutions, The World Bank, 2005.

[7] Phan. M. H, Education, Hanoi: National Political Publishing House, 2003.

[8] Pham. B. L, Vietnam Education in the early decades 21st century: Development Strategy, Hanoi: Education Publishing House, 2003.

[9] Central Propaganda Department, Fundamental and comprehensive reform of Vietnamese education and training, Hanoi: National Political Publishing House, (2005).

[10] Nhat. H, Vietnam's educational picture after 5 years of "Comprehensive fundamental renovation".https://dantri.com.vn/giao-duc-

khuyen-hoc/buc-tranh-giao-duc-viet-nam-sau-5nam-doi-moi-can-ban-toan-dien20181013111401235.htm, 2020.

[11] General Statistics Office, Vietnam Statistical Yearbook 2019. Hanoi: Statistics, 2020, pp. $717-$ 721,120

[12] Pham. B. L, Vietnam Education in the early decades 21st century: Development Strategy, Hanoi: Education Publishing House, 2003.

[13] Pham. M. H, Regarding comprehensive human development in the period of industrialization and modernization, Hanoi: National Political, 2001.

[14] Tran. K. D. Education and human resource development in the twenty-first century, Hanoi: Vietnam Education, 2010 